\title{
Relationships between professional burnout and job demands, resources among workers in an industrial plant in Lithuania
}

\author{
Aurelija Stelmokiene ${ }^{1, *}$, Giedre Geneviciute-Janone ${ }^{1}$, and Loreta Gustainiene ${ }^{1}$, \\ and Kristina Kovalcikiene ${ }^{1}$ \\ ${ }^{1}$ Vytautas Magnus University, Faculty of Social Sciences, Department of Psychology, Kaunas, \\ Lithuania
}

\begin{abstract}
Burnout can negatively affect both workers' health and safety in an organization [1]. The current study was oriented to identify the main risk and protective factors, which might predict professional burnout among workers in an industrial plant in Lithuania using the Job demands-resources model [2, 3]. 249 industrial and 74 administrative workers from one organization filled out a self-administered questionnaire. Scales from COPSOQ II (Copenhagen Psychosocial Questionnaire) were used in a cross-sectional survey. With reference to the research results, there were no significant differences in professional burnout between industrial and administrative workers. However, scores of work pace, safety climate, possibilities for development, influence at work, recognition and organizational justice were higher in a group of administrative employees as compared to their colleagues from the industrial departments. Moreover, different factors were found to predict employees' physical, emotional and mental exhaustion: emotional demands predicted burnout in administrative workers' group, while quantitative demands, work-family conflict, possibilities for development- among industrial workers. Organizational justice was the only protective factor to predict lower burnout in both groups of employees.
\end{abstract}

\section{Introduction}

In 2019 the World Health Organization [4] included professional burnout in the 11th Revision of the International Classification of Diseases (ICD-11) as an occupational phenomenon. However, human resource managers have become interested in this issue in organizations much earlier. Research findings confirmed that burnout could negatively affect workers' health, productivity and even safety in an organization [1].

Safety issues are especially important in an industrial sector. Therefore, the current study was oriented towards identifying main risk and protective factors predicting professional burnout among industrial workers in a chemical plant in Lithuania. Job demands-resources model $[2,3]$ was used to identify the main factors which could be related to employees' physical, emotional and mental exhaustion. It was hypothesized that higher scores on job demands would be associated with higher professional burnout, while increased scores of job resources would show the negative relationship to the strain of employees.

\footnotetext{
*Corresponding author: aurelija.stelmokiene@vdu.lt
} 
The WHO defined burnout as a syndrome resulting from chronic workplace stress that has not been successfully managed. Stress in the workplace could relate to particular task, social and organizational issues. Therefore, practitioners prefer recommendations for a specific sector to universal ones. Usually, burnout is investigated in health, education, social care sectors (with reference to Google Scholar search). This tendency even more increased during COVID-19 pandemic. However, research in industrial sector is scarce and provides ambiguous results. Ahola with colleagues [5] stated that burnout, especially work-related exhaustion, might hamper survival in a particular group of industrial employees. Meanwhile, Toppinen-Tanner, Kalimo and Mutanen [6] found that there were no differences between the two occupational groups (white and blue-collar jobs in international industry enterprise) in the process of burnout. Additionally, job stressors were very similar. So, the question remains whether similar or different job demands and resources predict professional burnout of industrial and administrative employees working in an industrial sector.

\section{Theoretical background}

\subsection{Professional burnout among different employees' groups}

The World Health Organization conceptualizes burnout as a syndrome resulting from chronic workplace stress that has not been successfully managed. Burnout is included in the 11th Revision of the International Classification of Diseases among the reasons for which people contact health services, but are not classified as illnesses or health conditions [4].

It is also important to acknowledge that "burnout is not a problem of individuals but of the social environment in which they work. $<\ldots>$ When the workplace does not recognize the human side of work, and there are major mismatches between the nature of the job and the nature of people, there will be a greater risk of burnout" [7].

As burnout is associated not only with work environment, but also with the employee him/herself, it is important that job and personal characteristics should be studied within the organizational environment at the same time. These job-related factors (organizational risk factors) may be arranged within six important areas of the workplace context [7]: workload, control (i.e., how much autonomy the personnel have over their work), reward (i.e., positive feedback and recognition), community (i.e., the quality of personal relationship and teamwork interaction), fairness (i.e., trust, openness, and respect in the workplace), and values (i.e., individual's aspirations, motivation, and ideals in their job). Any mismatch or imbalance between the person and the six areas of the job may intensify the likelihood of burnout [8]. Therefore, burnout is costly both for the organization and the employees: its negative impact is associated with various types of unfavourable organizational outcomes, such as absenteeism, varieties of somatic and mental health problems [8].

Research findings demonstrate high prevalence of burnout, especially in the so-called helping professions. In a series of studies conducted during 1992-2000 of the total of 9503 Dutch workers in 28 different occupations in which the tasks involved much contact with the recipients of services (usually patients) revealed that burnout was related to employees' possibilities to exert influence on their own work situation [9]. Prevalence of primary care providers' burnout in the US ranged from $13.5 \%$ to $60 \%$ [10]. In a study of university teachers in Lithuania, 42.8 percent of them indicated that they often or permanently suffer from professional burnout [11].

The data derived from 1807 participants from the first phase of the employees' health cohort in 2017-2018 revealed that being a single woman, health care provider, and having more than 20 years of work experience with a duty shift were contributing factors for burnout 
experience among Iranian health care employees [12]. High burnout risk was found in 41 percent $(N=575)$ of the US anaesthesiology residents [13].

Research evidence demonstrates that specific job characteristics clearly predict the predisposition of subjects to suffer from burnout-related symptoms. In this sense, accumulated evidence has demonstrated the existence of higher rates of objective stressors and lack of social support, as well as elevated rates of unfavourable outcomes (e.g. absenteeism, occupational incidents), in certain groups of workers, among which are health service providers, caregivers, professional drivers and correctional officers [14].

To sum up, research findings demonstrate, that burnout can evolve in all kinds of vocational groups [15], although prevailing research data indicate high prevalence of burnout among helping professions. It is evident that job burnout carries numerous adverse outcomes for the organization and their employees. On the organizational level, employee burnout is found to be linked with absenteeism, turnover, and inadequate job performance. On personal level, studies have shown that burnout is associated with headaches, type 2 diabetes, cardiovascular problems, insomnia, depression, and anxiety [16]. Thus, there are two paths to dealing with burnout: the individual path, and the organizational path [7].

The Job Demands Resources (JD-R) model, incorporating these two paths, can be used as an integrative conceptual framework for monitoring the workplace with the aim to increase work engagement and prevent burnout [17].

\subsection{Risk and safety factors for the professional burnout}

Within the occupational health sciences, prevailing theoretical models emphasize the complex and multidimensional nature of the psychosocial work environment as a determinant of worker health and well-being [18]. The National Psychosocial Work Environment Survey $(n=6408)$, providing the portrait of the psychosocial work environment in Canada, proposed the following six-factor latent structure of the psychosocial work environment that was measured using items from the Copenhagen Psychosocial Questionnaire (COPSOQ): (1) job demands, (2) job control and meaning, (3) co-worker support, (4) supervisor support, (5) justice, trust, and rewards, and (6) job security.

Psychosocial work characteristics are used to constitute various theoretical models, such as demand-control model, effort-reward imbalance and job demands-resources models, which highlight the role that multiple interacting job stressors play in the aetiology of occupational injury and illness $[19,20]$. One of such widely used models is the Job Demands Resources (JD-R) model.

According to the Job Demands-Resources (JD-R) model, every job includes demands as well as resources. W. Schaufeli [17] proposes that the JD-R model can be used as an integrative conceptual framework for monitoring the workplace with the aim to increase work engagement and prevent burnout. When job demands are at the increased level and not compensated by job resources, "employee's energy is progressively drained", and may result in "negative outcomes for the individual (e.g., poor health) as well as for the organization (e.g., poor performance)" [17 p. 2]. Additionally, decreasing job demands, increasing job (and personal) resources and stimulating 'engaged' leadership prevent burnout and increase work engagement [17].

In the present study, the Job demands-resources model $[2,3]$ was used to determine the main factors that could be related to employees' physical, emotional and mental exhaustion. It was hypothesized that higher scores on job demands would be associated with higher professional burnout, while increased scores of job resources would show the negative relationship to burnout of employees. 


\subsubsection{Job demands}

Job demands are characteristics that could consume energetic resources and even deplete energy [21]. Quantitative, emotional demands and work pace are among the most studied task demands.

Emotional demands are defined as job demands that require sustained emotional efforts during the interaction with clients. Emotional demands are important when predicting burnout of employees in human service sector [22]. Quantitative demands and work pace are classified as psychological demands [22]. They are defined as psychological stressors involved in accomplishing tasks at work [23, 24]. Quantitative demands relate to the amount of work to be done in a limited time. The pace of work reflects whether the employee has to work intensively throughout the day.

Safety climate also can be categorized as job demand and is conceptualised as the individual's psychological perception of the degree of an organization's safety and the status of its progress in consciousness and belief [25]. More precisely, safety climate is a corporate environment, involving people's perspective of and beliefs in the organization for safety policy and safety services, safety management and organization attitudes and safety supervision [25]. Safety climate is regarded as an organizational factor of job demands. Workers especially transport, construction, manufacturing, and service workers are more likely to experience safety problems and accidents at work [26].

Work-family conflict is mentioned among personal aspects of job demands. Work-tofamily conflict occurs when the pressures from the work and family domains are mutually incompatible, and as a result, participation in the family role is made more difficult by virtue of participation in the work role [27]. The notion of role conflict comes from scarcity theory [28], which assumes that personal resources, such as time and energy, are finite and that the devotion of greater resources to one role necessitates the devotion of lesser resources to other roles. Work-family conflict has an array of negative consequences, including lower job and family satisfaction, lower career satisfaction, organizational commitment, job performance, and organizational citizenship behaviours [29, 30]. Work-family conflict is also associated with higher turnover intentions, absenteeism, stress, burnout, and exhaustion [31, 32].

\subsubsection{Job resources}

Job resources are physical, social or organizational aspects of the job that could help achieve work-related goals, reduce job demands and contribute to personal development [33]. According to the Conservation of Resources theory "stress occurs (a) when central or key resources are threatened with loss, (b) when central or key resources are lost, or (c) when there is a failure to gain central or key resources following significant effort" [34 p. 104].

At work one can distinguish several groups of resources [35]:

- task related resources (e. g. possibilities for development, meaning of work, influence at work);

- social/ relational resources (e.g. trust, social support), and

- organizational resources - justice, recognition.

Earlier studies focused on different psychosocial characteristics when analysing their relationship to negative health outcomes. Psychosocial work characteristics (more quantitative demands, job insecurity and less possibilities for development, influence at work, social support from supervisors and co-workers) in a 5-year follow-up study contributed to the development of severe depressive symptoms in the Danish workforce. Different aspects of the psychosocial work environment were important for men and women [36]. Psychosocial work characteristics (decision authority, job variety, social support at work, and effort and reward 
at work) were related to self-rated health in population samples of working men and women in four post-communist countries [37].

There is a widespread agreement that social support is a very important resource in the working context with positive effects on health, well-being, and job satisfaction, which employees and organisations can benefit from. Both supervisors and co-workers play important roles in providing support at the workplace, with supervisors presumably having some greater impact. The beneficial outcomes of social support from supervisors and colleagues on employees' health and work have been extensively reflected in literature [11, 38, 39].

Trust is formed in the process of social exchange between two parties [40] in an organizational context it is reflected by the level of employee-organization relationship (EOR) [40]. Therefore, EOR may be considered an important predictor of an organizational trust. The study by $\mathrm{Yu}$ and colleagues has revealed that organizational trust was an important mediating mechanism between EOR and innovative behaviour [41].

The term "organizational justice" refers to the extent to which employees perceive workplace procedures, interactions, and outcomes as fair in nature [42]. Organizational justice has been linked to job performance at the individual, team, and organizational level, including both task and contextual performance. Organizational justice has been associated with employee health and well-being [43]. In their study, Maslach and Leiter found that unfair behaviour was likely to develop into burnout in the course of time [47]. Organizational justice is also linked to negative outcomes such as counterproductive work behaviour and turnover. Therefore, those who perceive fairness in outcomes and processes tend to engage less in these negative behaviours [45].

Recognition is generally defined as the assignment of personal non-monetary rewards (i.e., interest, approval, and appreciation) for individual efforts and work accomplishment to recognize and reinforce the desired behaviours displayed by an employee [46]. Employee recognition can boost productivity and increase satisfaction [47], empirical evidence demonstrated that managerial non-monetary recognition positively contributed to employee psychological well-being [48, 47]. The study by Montani and Boudrias[46] is in line with previous research, stating that "the emission of consistent signs of appreciation from managers and co-workers is essential to optimise the motivational benefits of recognition to employee behavioural involvement at work“ [47 p. 22].

\subsubsection{Job demands-resources and professional burnout in different employees' groups in an organization}

As can be seen from research, burnout can evolve in all kinds of vocational groups [15], although prevailing research data indicate high prevalence of burnout among helping professions. Research findings [37, 22, 26, 32, 11, 6] also demonstrate that both job demands and resources, and their relationship with burnout may differ depending on the specific professional groups. This may relate to the different tasks employees perform in their positions within the same organization. For example, administrative staff may significantly differ from other positions in industrial organizations, because their work may relate to working with clients and/or employees in other positions of the same organization. Their job demands as well as job resources may differ from that of other, especially industrial, positions. The tasks that administrative staff performs may relate to increased workload [53]. Moreover, administrative duties in health sector required substantial physician's time and affected physicians' perceptions of being able to deliver high-quality care, to feel career satisfaction instead of burnout, and less likely to continue clinical practice [54]. Although relation with burnout 
among helping professions has been extensively studied relatively little attention is given to the analysis of these factors among administrative staff and industrial workers.

With reference to the literature findings presented above, it was hypothesized that:

a) higher scores on job demands would be associated with higher professional burnout, while increased scores of job resources would show the negative relationship to burnout of employees;

b) different job demands and job resources would predict professional burnout depending on employees' positions (i.e., industrial and administrative positions).

\section{Research methodology}

\subsection{Procedure and participants}

265 industrial workers (74 percent of males and 23.4 percent of females, 2.6 percent did not indicate their sex) and 74 administrative workers (46 percent of males and 54 percent of females) from one chemical plant in Lithuania participated in the research in autumn 2020.

45.9 percent of administrative emploees had work experience 11 to 20 years, and 31.1 percent had more than 20 years of employment. 20 percent of industrial workers had work experience from 1 to 5 years, 28.6 percent 11 to 20 years and 37.6 of them had more than 20 years of work experience.

64.8 percent of administrative personnel and 73.1 percent of industrial workers did not have subordinates.

Other socio-demographic data have not been collected at the organization's request in order to ensure anonymity of employees.

\subsection{Measures}

Participants filled out a self-administered questionnaire in a cross-sectional survey. Perceived job demands, resources and professional burnout were measured via the Copenhagen Psychosocial Questionnaire (COPSOQ II, 2007) [49] scales and the Safety Climate scale [50]. In the present research, job resources (protective factors) included possibilities for development, meaning of work, influence at work, social support: from colleagues and supervisor, horizontal and vertical trust, organizational justice, recognition. Job demands (risk factors) in this research were quantitative demands, emotional demands, work pace, safety climate, work-family conflict.

Detailed information about the instruments is presented in Table 1. Due to low internal consistency, horizontal and vertical trust was removed from further analysis.

Socio-demographic characteristics of respondents were also included in the questionnaire. Voluntary participation in the research and confidentiality were guaranteed. The response rate was 30.3 percent.

\subsection{Strategy of analyses}

Descriptive statistics of the main research phenomena are introduced below. The correlation matrix, mean scores, and standard deviations for all the main variables in this survey are presented in Table 2. T-test was used to compare professional burnout, job demands, and job resources between industrial and administrative employees. Finally, linear regression analysis was used to identify the main risk and protective factors of professional burnout between these two groups of employees. 
Table 1. Information about the survey scales.

\begin{tabular}{|c|c|c|c|c|}
\hline Phenomena & Scales & $\begin{array}{c}\text { No of } \\
\text { statements }\end{array}$ & Examples of statements & $\begin{array}{l}\text { Cronbach's } \\
\text { alpha }\end{array}$ \\
\hline $\begin{array}{c}\text { Professional } \\
\text { burnout }\end{array}$ & $\begin{array}{l}\text { Professional } \\
\text { burnout }\end{array}$ & 4 & $\begin{array}{c}\text { How often (during the last } 4 \\
\text { weeks) have you felt worn } \\
\text { out? }\end{array}$ & .890 \\
\hline \multirow[t]{7}{*}{ Job resources } & $\begin{array}{l}\text { Possibilities for } \\
\text { development }\end{array}$ & 4 & $\begin{array}{c}\text { Does your work give you } \\
\text { the opportunity to develop } \\
\text { your skills? }\end{array}$ & .850 \\
\hline & Meaning of work & 3 & $\begin{array}{c}\text { Do you feel that the work } \\
\text { you do is important? }\end{array}$ & .810 \\
\hline & Influence at work & 4 & $\begin{array}{l}\text { Do you have any influence } \\
\text { on what you do at work? }\end{array}$ & .747 \\
\hline & $\begin{array}{c}\text { Social support: } \\
\text { from colleagues and } \\
\text { leader }\end{array}$ & $\begin{array}{l}3 \\
3\end{array}$ & $\begin{array}{l}\text { How often do you get help } \\
\text { and support from your } \\
\text { colleagues (nearest } \\
\text { superior)? }\end{array}$ & $\begin{array}{l}.835 \\
.880\end{array}$ \\
\hline & $\begin{array}{l}\text { Trust: horizontal, } \\
\text { vertical }\end{array}$ & $\begin{array}{l}3 \\
3\end{array}$ & $\begin{array}{l}\text { Do the employees in } \\
\text { general trust each other? }\end{array}$ & $\begin{array}{l}.591 \\
.565\end{array}$ \\
\hline & $\begin{array}{l}\text { Organizational } \\
\text { justice }\end{array}$ & 4 & $\begin{array}{l}\text { Is the work distributed } \\
\text { fairly? }\end{array}$ & .846 \\
\hline & Recognition & 2 & $\begin{array}{l}\text { Is your work recognised } \\
\text { and appreciated by the } \\
\text { management? }\end{array}$ & .826 \\
\hline \multirow[t]{5}{*}{ Job demands } & $\begin{array}{l}\text { Quantitative } \\
\text { demands }\end{array}$ & 4 & $\begin{array}{c}\text { Do you get behind with } \\
\text { your work? }\end{array}$ & .699 \\
\hline & Emotional demands & 4 & $\begin{array}{l}\text { Is your work emotionally } \\
\text { demanding? }\end{array}$ & .767 \\
\hline & Work pace & 3 & $\begin{array}{l}\text { Do you work at a high pace } \\
\text { throughout the day? }\end{array}$ & .913 \\
\hline & Safety climate & 16 & $\begin{array}{c}\text { My suggestions about } \\
\text { safety would be acted upon } \\
\text { if I expressed them to } \\
\text { management. }\end{array}$ & .887 \\
\hline & $\begin{array}{l}\text { Work-family } \\
\text { conflict }\end{array}$ & 4 & $\begin{array}{l}\text { Do your friends or family } \\
\text { tell you that you work too } \\
\text { much? }\end{array}$ & .881 \\
\hline
\end{tabular}

\section{Results}

\subsection{Relationship between job demands, job resources, and professional burnout}

The correlation analysis was employed in order to test the first hypothesis, which presumed that higher scores on job demands would be associated with higher professional burnout, while increased scores of job resources would show the negative relationship to burnout of employees at work. Table 2 shows that professional burnout correlates positively with such job demands as quantitative $(p<.01)$ and emotional job demands $(p<.01)$, work pace at work $(p<.01)$ as well as work-family conflict $(p<.01)$. Additionally, professional burnout was found to be negatively correlated with safety climate $(p<.01)$. 


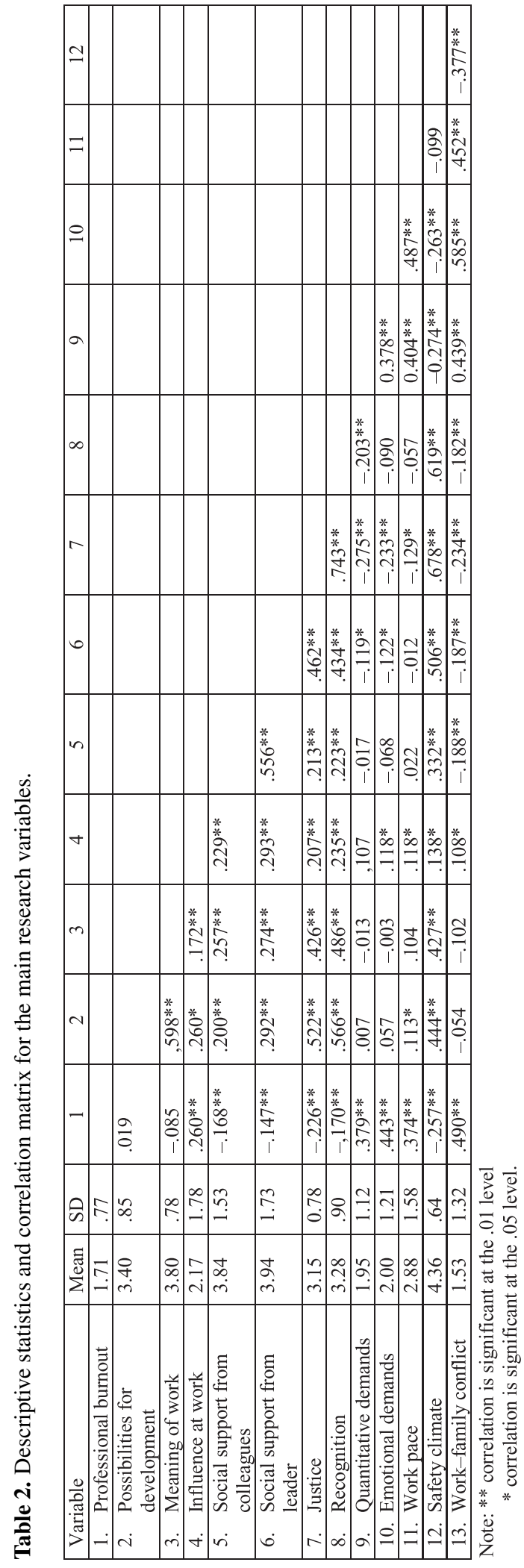


Analysis of job resources show that the more employees feel influential $(p<.01)$ and receiving recognition at work $(p<.01)$ the less burnout they feel. Additionally, increase in scores on social support from colleagues $(p<.01)$ and supervisors $(p<.01)$ are related to the decrease in scores of burnout. In addition, organizational justice $(p<.01)$ was negatively related to professional burnout.

\subsection{Professional burnout, job demands, and job resources among industrial and administrative workers}

Student's $t$-test was used to compare professional burnout as well as job demands and job resources between administrative and industrial workers (Table 3). The results show that there is no significant difference between administrative and industrial workers' professional burnout $(p>.05)$. Nevertheless, employees from administration indicated working at a higher pace as compared to their colleagues from the industrial departments $(p<.001)$. Administrative workers pay more attention to safety climate than industrial workers $(p<.001)$. The analysis also revealed that administrative workers realized they had more possibilities for development $(p<.01)$ as well as influence at work $(p<.05)$ than industrial workers. The scores on recognition $(p<.001)$ and organizational justice $(p<.001)$ were higher in the group of administrative workers than that of industrial workers.

Table 3. Comparison of the main research variables among administrative and industrial workers.

\begin{tabular}{|c|c|c|c|c|c|c|}
\hline Variable & Positions & $\mathrm{N}$ & Mean & $\begin{array}{c}\text { Std. } \\
\text { Deviation }\end{array}$ & $t(d f)$ & $\begin{array}{c}\text { Sig. } \\
\text { (2- } \\
\text { tailed) }\end{array}$ \\
\hline \multirow{2}{*}{$\begin{array}{l}\text { 1. Professional } \\
\text { burnout }\end{array}$} & Administrative & 74 & 1.69 & .79 & \multirow{2}{*}{$\begin{array}{r}-.312 \\
(334)\end{array}$} & \multirow{2}{*}{.755} \\
\hline & Industrial & 262 & 1.72 & .77 & & \\
\hline \multirow{2}{*}{$\begin{array}{l}\text { 2. Possibilities for } \\
\text { development }\end{array}$} & Administrative & 74 & 3.70 & .92 & \multirow{2}{*}{$\begin{array}{l}3.468 \\
(337)\end{array}$} & \multirow[t]{2}{*}{.001} \\
\hline & Industrial & 265 & 3.32 & .81 & & \\
\hline \multirow{2}{*}{$\begin{array}{l}\text { 3. Meaning of } \\
\text { work }\end{array}$} & Administrative & 74 & 3.88 & .84 & \multirow{2}{*}{$\begin{array}{l}1.000 \\
(337)\end{array}$} & \multirow[t]{2}{*}{.318} \\
\hline & Industrial & 265 & 3.78 & .76 & & \\
\hline \multirow{2}{*}{$\begin{array}{l}\text { 4. Influence at } \\
\text { work }\end{array}$} & Administrative & 74 & 2.53 & 1.46 & \multirow{2}{*}{$\begin{array}{l}2.585 \\
(336)\end{array}$} & \multirow[t]{2}{*}{.010} \\
\hline & Industrial & 264 & 2.07 & 1.34 & & \\
\hline \multirow{2}{*}{$\begin{array}{l}\text { 5. Social support } \\
\text { from colleagues }\end{array}$} & Administrative & 74 & 3.77 & 1.41 & \multirow{2}{*}{$\begin{array}{r}-.472 \\
(330)\end{array}$} & \multirow[t]{2}{*}{.637} \\
\hline & Industrial & 258 & 3.87 & 1.57 & & \\
\hline \multirow{2}{*}{$\begin{array}{l}\text { 6. Social support } \\
\text { from supervisor }\end{array}$} & Administrative & 74 & 4.21 & 1.50 & \multirow{2}{*}{$\begin{array}{l}.661 \\
(137.587)\end{array}$} & \multirow[t]{2}{*}{.099} \\
\hline & Industrial & 261 & 3.87 & 1.79 & & \\
\hline \multirow{2}{*}{$\begin{array}{l}\text { 7. Organizational } \\
\text { justice }\end{array}$} & Administrative & 74 & 3.43 & .81 & \multirow{2}{*}{$\begin{array}{l}3.581 \\
(336)\end{array}$} & \multirow[t]{2}{*}{.000} \\
\hline & Industrial & 264 & 3.07 & .76 & & \\
\hline \multirow[t]{2}{*}{ 8. Recognition } & Administrative & 74 & 3.66 & .82 & \multirow{2}{*}{$\begin{array}{l}4.162 \\
(331)\end{array}$} & \multirow[t]{2}{*}{.000} \\
\hline & Industrial & 259 & 3.17 & .89 & & \\
\hline \multirow{2}{*}{$\begin{array}{l}\text { 9. Quantitative } \\
\text { demands }\end{array}$} & Administrative & 74 & 1.99 & 1.17 & \multirow{2}{*}{$\begin{array}{l}.324 \\
(336)\end{array}$} & \multirow[t]{2}{*}{.746} \\
\hline & Industrial & 264 & 1.94 & 1.10 & & \\
\hline \multirow{2}{*}{$\begin{array}{l}\text { 10. Emotional } \\
\text { demands }\end{array}$} & Administrative & 74 & 2.05 & 1.18 & \multirow{2}{*}{$\begin{array}{l}.392 \\
(336)\end{array}$} & \multirow[t]{2}{*}{.695} \\
\hline & Industrial & 264 & 1.98 & 1.21 & & \\
\hline \multirow[t]{2}{*}{ 11. Work pace } & Administrative & 74 & 3.48 & 1.43 & \multirow{2}{*}{$\begin{array}{l}3.735 \\
(335)\end{array}$} & .000 \\
\hline & Industrial & 263 & 2.72 & 1.59 & & \\
\hline 12. Safety climate & Administrative & 70 & 4.63 & .60 & 4.209 & .000 \\
\hline & Industrial & 240 & 4.27 & .64 & $(308)$ & \\
\hline 13. Work-family & Administrative & 74 & 1.61 & 1.33 & .647 & .518 \\
\hline conflict & Industrial & 264 & 1.50 & 1.32 & (336) & \\
\hline
\end{tabular}




\subsection{Risk and protective factors predicting professional burnout in two groups of employees}

Linear regression analysis using a two-step enter method was employed for the main data analysis separately among administrative and industrial workers to determine risk and protective factors predicting professional burnout in these groups. In the first step only job demands (i.e., quantitative demands, emotional demands, work pace, safety climate, and work-family conflict) were entered to the model as predictors of professional burnout for both samples of administrative and industrial workers. In the second step, job resources (i.e., possibilities for development, meaning of work, influence at work, social support from colleagues, and social support from leader, organizational justice, and recognition) were added. In the regression analysis all job demands and job resources were entered to the model as predictors of professional burnout (as the dependant variable). Empirical data showed (see Tables 4 and 5) that regression models for administrative and industrial workers were statistically significant.

In the sample of administrative workers, all predictors together explained 39.4 percent of professional burnout variance in the final model. F change $(.874, p>.05)$ was not significant in the second step of the linear regression analysis with enter method and R square did not increase significantly with insertion of job resources ( $\mathrm{R}$ squared change $=.068$ ). Only by adding job resources in the analysis, one of job demands became a significant variable in predicting professional burnout. As table 4 shows, none of the job demands variables was significantly related to professional burnout in the first step. When analysing job demands and job resources together, only higher emotional demands $(p<0.05)$ were important predictors of stronger professional burnout, and the feeling of greater justice at work helped to predict less burnout.

Table 4. Prediction of professional burnout among administrative workers (results of linear regression analysis).

\begin{tabular}{|c|c|c|c|c|}
\hline Model & Predictor & $\begin{array}{c}\text { Standardized } \\
\text { coefficient } \\
\text { Beta }\end{array}$ & $\mathrm{t}(\mathrm{p})$ & $F(p)$ \\
\hline \multirow{5}{*}{ Job demands } & Quantitative demands & .114 & $.875(.385)$ & \multirow{5}{*}{$\begin{array}{l}5.380 \\
(<.001)\end{array}$} \\
\hline & Emotional demands & .171 & $1.255(.214)$ & \\
\hline & Work pace & .070 & $.593(.555)$ & \\
\hline & Safety climate & -.146 & $-1.299(.199)$ & \\
\hline & Work-family conflict & .251 & $1.695(.095)$ & \\
\hline \multirow{12}{*}{$\begin{array}{l}\text { Job demands }+ \\
\text { job resources }\end{array}$} & Quantitative demands & .210 & $1.447(.153)$ & \multirow{12}{*}{$\begin{array}{l}2.721 \\
(.006)\end{array}$} \\
\hline & Emotional demands & .339 & $2.111(.039)$ & \\
\hline & Work pace & .028 & $.224(.824)$ & \\
\hline & Safety climate & -.306 & $-1.462(.149)$ & \\
\hline & Work-family conflict & .052 & $.267(.790)$ & \\
\hline & Possibilities for development & -.028 & $-.139(.890)$ & \\
\hline & Meaning of work & .018 & $.095(.925)$ & \\
\hline & Influence at work & .034 & $.281(.780)$ & \\
\hline & Social support from colleagues & -.068 & $-.429(.670)$ & \\
\hline & Social support from leader & .025 & $.162(.872)$ & \\
\hline & Organizational justice & -.442 & $2.192(.033)$ & \\
\hline & Recognition & -.221 & $-1.189(.239)$ & \\
\hline
\end{tabular}

Analysis in the industrial workers group showed that both groups of predictors (job demands and job resources) together explained 31.5 percent of professional burnout variance. In contrast to the administration sample, the second step of the linear regression analysis 
with enter method was significant $(\mathrm{F}$ change $=2.131, p<.05)$ and $\mathrm{R}$ square increased with insertion of additional variables from .306 to .352 .

Table 5. Prediction of professional burnout among industrial workers (results of linear regression analysis).

\begin{tabular}{|c|c|c|c|c|}
\hline Model & Predictor & $\begin{array}{l}\text { Standardized } \\
\text { coefficient } \\
\text { Beta }\end{array}$ & $\mathrm{t}(\mathrm{p})$ & $\mathrm{F}(\mathrm{p})$ \\
\hline \multirow{5}{*}{ Job demands } & Quantitative demands & .146 & $2.227(.027)$ & \multirow{5}{*}{$\begin{array}{l}19.323 \\
(<.001)\end{array}$} \\
\hline & Emotional demands & .123 & $1.631(.104)$ & \\
\hline & Work pace & .167 & $2.297(.023)$ & \\
\hline & Safety climate & -.045 & $-0.712(.477)$ & \\
\hline & Work-family conflict & .238 & $3.017(.003)$ & \\
\hline \multirow{12}{*}{$\begin{array}{l}\text { Job demands + } \\
\text { job resources }\end{array}$} & Quantitative demands & .158 & $2.395(.018)$ & \multirow{12}{*}{$\begin{array}{l}9.585 \\
(.006)\end{array}$} \\
\hline & Emotional demands & .144 & $1.930(.055)$ & \\
\hline & Work pace & .028 & $.224(.824)$ & \\
\hline & Safety climate & .049 & $.572(.568)$ & \\
\hline & Work-family conflict & .241 & $3.004(.003)$ & \\
\hline & Possibilities for development & .186 & $2.435(.016)$ & \\
\hline & Meaning of work & -.138 & $-1.938(.054)$ & \\
\hline & Influence at work & -.083 & $-1.328(.186)$ & \\
\hline & $\begin{array}{l}\text { Social support from } \\
\text { colleagues }\end{array}$ & -.114 & $-1.649(.101)$ & \\
\hline & Social support from leader & .081 & $1.051(.295)$ & \\
\hline & Organizational justice & -.221 & $-2.223(.027)$ & \\
\hline & Recognition & .065 & $.718(.473)$ & \\
\hline
\end{tabular}

By including only job demands variables in the regression analysis higher quantitative demands $(p<.05)$, work pace $(p<.05)$ and more common work-family conflicts $(p<.01)$ are significant predictors of stronger professional burnout in industrial workers sample (see Table 5). However, in the second regression step, adding job resource variables work pace becomes insignificant $(p>.05)$. Besides, justice $(p<.05)$ became associated with less burnout. However, industrial workers are more likely to burn out as possibilities for development increase $(p<.05)$.

\section{Discussion}

Based on the Job Demands-Resources model [2, 3] it was hypothesized that (a) higher scores on job demands would be associated with higher professional burnout, while increased scores of job resources would show the negative relationship to burnout of employees. An additional important contribution of this study is the effort to answer the question whether similar or different job demands and resources predict professional burnout of industrial and administrative workers, thus the second hypothesis assumes that (b) different job demands and job resources can predict professional burnout depending on employees' positions (i.e., industrial and administrative positions).

It can be stated that the results of the study confirmed the first hypothesis (a): four of five studied job demands such as quantitative demands, emotional demands, work pace and work-family conflict (except safety climate) are related to higher professional burnout. In addition, job resources such as social support from colleagues, social support from supervisor, justice, and recognition are negatively related to burnout of employees, although influence at work was positively related. Our results confirm the results of other researchers in this 
field regarding job demands [22, 23, 24, 31] and job resources [11, 38, 39, 43, 45, 47, 48]. It can be noted that social support from supervisors and co-workers [39, 38, 36, 37, 11], as well as organizational justice $[42,45,43,44]$ are crucial resources in the workplace, leading to experiencing less burnout. Recognition of employees is very important because it proves that others value their work. These findings complement the results of other researchers, who emphasized the value of mentioned factors to employee psychological well-being [20, 8, 48, 18]. It was also found that professional burnout is negatively related with safety climate. Especially in industrial organizations, employees' perspective of and beliefs in the organization for safety policy and safety practices are extremely important $[25,26]$. The results of this study emphasize that in order to ensure a safe climate in an industrial organization, it is very important to take care of the health of employees, paying attention to the level of burnout.

According to the analysis of professional burnout depending on different employees' positions, the research revealed that there were no significant differences in professional burnout between industrial and administrative workers. These findings confirm the results of similar studies that burnout can evolve in all kinds of vocational groups [15].However, regarding risk factors for employees' physical, emotional and mental exhaustion between industrial and administrative workers, the findings showed significant differences. The results indicated that administrative employees scored higher on both perceived demands and resources (influence at work, organizational justice, recognition, work pace, safety climate, and possibilities for development) as compared to industrial workers. This is consistent with research findings of others [37, 22, 26, 32, 11, 6], which demonstrate that job demands and resources may differ depending on the specific professional groups. Such results can be explained by the fact that administrative workers tend to perform more mentally complex, less defined tasks and perform much more varied professional roles than industrial workers, whose tasks are more concentrated / specialized.

Finally, the results of the study also confirmed the second hypothesis (b) that different factors were significant in predicting employees' physical, emotional and mental exhaustion in different groups of employees' position (i.e., industrial and administrative positions). The results revealed that emotional demands and organizational justice were significant in predicting professional burnout for the sample of administrative workers. These results are consistent with the results of other studies showing that emotional demands are important when predicting burnout of employees in the human service sector [22]. One can argue that emotional efforts during face-to-face or even remote interaction with others could consume or deplete energy [21]. Thus, emotional requirements are inevitable characteristics of services that involve working with human resources, which is common for administrative workers. As mentioned above, this is possible due to the administrative staff performing multiple roles that need to be reconciled in relation to the employee (e.g., from support provider to manager who gives clear instructions to achieve unit's/organization's goals). This also confirms the research conducted in Lithuania [11] that quantitative and emotional demands were the major factors predicting professional burnout among university teachers. In this research like in other studies [42, 45, 43, 44] organizational justice was a crucial resource in the workplace, leading to experiencing less burnout. That is true both for administrative and industrial workers. Organizational justice, quantitative demands, work-family conflict, and possibilities for development had significant prognostic value for professional burnout among industrial workers. This means that psychological stressors such as the amount of work to be done in a limited time (quantitative demands) and the need to work at a steady and high pace [24, 22] requires the use of energy resources [21] in a group of industrial workers. These results can be explained by the fact that industrial workers may have less autonomy in their work, less participation in deciding how to organize their work, because they need to strictly adhere to rules and principles in performing their tasks in a very dangerous work environment (chem- 
ical products). Knight, Keller and Parker [51] also confirmed that job demands predicted psychological distress trajectories of employees during COVID-19. In their study, the load and close monitoring did predict rising distress. In addition, work-family conflict complicates participation in work [27] and leads to professional burnout. On the other hand, the need for professional development can contribute to the reduced levels of burnout [33]. However, in this case possibilities for development were related to higher professional burnout of industrial workers.

Some limitations about this research should also be mentioned. Firstly, the study involved non-equal sample sizes of employee groups. Secondly, the study was conducted in one organization. Thirdly, although COPSOQ II is a widely used and valid tool, it is nevertheless a self-administered questionnaire (social desirability may have occurred). Finally, the authors of this study would see the necessity of longitudinal research in this topic.

Further research should draw attention to additional protective factors for professional burnout beyond job resources. It was hypothesized that job resources should act as factors diminishing employees' physical, emotional, and mental exhaustion. However, higher possibilities for development and greater support from supervisors predicted higher professional burnout and distress [51], accordingly. Additionally, what may need to be considered but is beyond the scope of this paper is how contextual factors such as COVID-19 pandemic and quarantine could affect results of the study.

\section{References}

[1] T.D. Smith, C. Mullins-Jaime, M.A. Dyal, D.M. DeJoy. J Safety Res. 75, 189 (2020)

[2] A.B. Bakker, E. Demerouti. Wellbeing: A complete reference guide. 1 (2014)

[3] A.B. Bakker, E. Demerouti. J. Occup. Health Psychol. 22, 273 (2017)

[4] World Health Organization. Burn-out an occupational phenomenon: International Classification of Diseases (2019)

[5] K. Ahola, A. Väänänen, A. Koskinen, A. Kouvonen, A. Shirom. J. Psychosom. Res. 69(1), 51 (2010)

[6] S. Toppinen-Tanner, R. Kalimo, P. Mutanen. J. Organiz. Behav. 23(5), 555 (2002)

[7] Ch. Maslach, M.P. Leiter, SSIR (2005)

[8] Ch. Maslach, M.P. Leiter, World Psychiatry 15,103-111 (2016)

[9] T.W. Taris, J. Stoffelsen, A.B. Bakker, W.B. Schaufeli, D. van Dierendonck, Psychological Reports 97, 955-961 (2005)

[10] C.M. Abraham, K. Zheng, L. Poghosyan Med Care Res Rev 77, 387-401 (2020)

[11] A. Stelmokienè, G. Genevičiūtè-Janonè, L. Gustainienè, K. Kovalčikienè, Pedagogika 134, 25-44 (2019)

[12] E. Bazmi, A. Alipour, M.T. Yasamy, A. Kheradmand, S. Salehpour, S. Khodakarim, H. Soori, Iran J Psychiatry 14, 309-316 (2019)

[13] G.S. de Oliveira, Jr., R. Chang, P.C. Fitzgerald, M.D. Almeida, L.S. Castro-Alves, Sh.Ahmad, R.J. McCarthy, Anesthesia \& Analgesia 117, 182-193 (2013)

[14] S.A. Useche, L.V. Montoro, J. I. Ruiz, C. Vanegas, J. Sanmartin, E. Alfaro, PLoS ONE 14 (2019)

[15] K. Ahola, T. Honkonen, E. Isometsä, R. Kalimo, E. Nykyri, S. Koskinen, A. Aromaa, J. Lönnqvist, Soc. Psychiat. Epidemiol. 41, 11 (2006)

[16] T. Lubbadeh International Review of Management and Marketing 10, 7-15 (2020)

[17] W.B. Schaufeli, Organizational Dynamics 46, 120-132 (2017) 
[18] F.V. Shahidi, M.A.M. Gignac, J. Oudyk, P.M. Smith, Annals of Work Exposures and Health 65, 418-431 (2021)

[19] J. Siegrist, Historical and current perspectives on stress and health (2002)

[20] A.B. Bakker, E. Demerouti, J Manag Psych 22, 309-328 (2007)

[21] A.B. Bakker, E. Demerouti, Handbook of well-being (2018)

[22] N. van Vegchel, J. de Jonge, M. Söderfeldt, Ch. Dormann, J. Wolfgang, W. Schaufeli, International Journal of Stress Management 11, 21-40 (2004)

[23] R.A. Karasek, Administrative Science Quarterly 24, 285-308 (1979)

[24] T.S. Kristensen, J.B. Bjorner, K.B. CHristensen, V. Borg, Work \& Stress 18, 305-322 (2004)

[25] T. Luo, Journal of Safety Science and Resilience 1, 106-119 (2020)

[26] J. Ajslev, E.L. Dastjerdi, J. Dyreborg, P. Kines, K.Ch. Jeschke, E. Sundstrup, M.D. Jakobsen, N. Fallentin, L.L. Andersen, Safety Science 91, 320-325 (2017))

[27] C. Weer, J.H. Greenhaus, Encyclopedia of Quality of Life and Well-Being Research (2014)

[28] W. Goode, American Sociological Review 25, 483-496 (1960)

[29] F.T. Amstad, L.L. Meier, U. Fasel, A. Elfering, N.K. Semmer, Journal of Occupational Health Psychology 16, 151-169 (2011)

[30] H. Vaziri, G.S. Benson, M.S. Campo, Journal of Organizational Behavior (2019)

[31] C. Nohe, L.L. Meier, K. Sonntag, A. Michel, Journal of Applied Psychology 100, 1-15 (2015)

[32] T.D. Allen, K.A. French, S. Dumani, K.M. Shockley, Journal of Applied Psychology 105, 539-576 (2020)

[33] D. Xanthopoulou, A.B. Bakker, E. Demerouti, W.B. Schaufeli, International Journal of Stress Management 14, 121-141 (2007)

[34] S.E. Hobfoll, J. Halbesleben, J.-P. Neveu, M. Westman, Annu. Rev. Organ. Psychol. Organ. Behav 5, 103-128 (2018)

[35] C. Knight, S.K. Parker, Human Relations 74, 69-104 (2021)

[36] R. Rugulies, U. Bültmann, B. Aust, H. Burr, American Journal of Epidemiology 163, 877-887 (2006)

[37] H. Pikhart, M. Bobak, J. Siegrist, A. Pajak, S. Rywik, J. Kyshegyi, A. Gostautas, Z. Skodova,M. Marmot, J Epidemiol Community Health 55, 624-630 (2001)

[38] E.E. Kossek, SH. Pichler, T. Bodner, L.B. Hammer, Pers Psychol 64, 289-313 (2011)

[39] T.F. Harandi, M.M. Taghinasab, T. D. Nayeri Electronic Physician 9, 5212-5222 (2017)

[40] L.M. Shore, L.E. Tetrick, P. Lynch, K. Barksdale, J. Appl. Soc. Psychol. 36, 837-867 (2006)

[41] M.-Ch. Yu, Q. Mai,S.-B. Tsai, Y. Dai, Sustainability 10, 1-14 (2018)

[42] S. Baldwin, Organizational Justice, Institute for employment studies (2006)

[43] M. Kivimaki, J.E. Ferrie, J. Head, M.J. Shipley, J. Vahtera, M.G. Marmot, J Epidemiol Community Health 58, 931-937 (2004)

[44] Ch. Maslach, M.P. Leiter, Journal of Applied Psychology 93, 498-512 (2008)

[45] J.A. Colquitt, , B.A. Scott, J.B. Rodell, D.M. Long, C.P. Zapata, D.E. Conlon, M.J. Wesson, Journal of Applied Psychology 98, 199-236 (2013)

[46] F. Montani, J.-S. Boudrias, M. Pigeon, The International Journal of Human Resource Management, 1-29 (2017)

[47] M.T. Tessema, K.J. Ready, A.B. Embaye, Journal of Business and Economics 4, 1-12 (2013) 
[48] D.M. Merino, J. Privado, Spanish Journal of Psychology 18, 1-7 (2015)

[49] Copenhagen Psychosocial Questionnaire (COPSOQ-II)

(2007) https://nfa.dk/da/Vaerktoejer/Sporgeskemaer/Copenhagen-PsychosocialQuestionnaire-COPSOQ-II/Engelsk-udgave

[50] J.B. Sexton, R.L. Helmreich, T.B. Neilands, K. Rowan, K. Vella, J. Boyden, P.R. Roberts, E.J. Thomas, BMC Health Serv. Res. 3, 6-44 (2006)

[51] S.K. Parker, C. Knight, A. Keller, Harvard Business Review (2021) 